\title{
Modernite ve Modernizm: Batı-İçi Bir Tartışma
}

\author{
Modernity and Modernism: An Intra-Western Debate
}

\author{
(iD) Fatmanur Altun \\ fatmanuraltun@gmail.com
}

Geliş Tarihi: 06 Mayıs 2021

Kabul Tarihi: 07 Temmuz 2021

Yayın Tarihi: 15 Temmuz 2021

Öz: Modernite (modernlik) ve modernizm kavramları gerek sosyal bilim yazınında gerekse gündelik hayatta sıkıkla karşımıza çıkan kavramlar olmalarına rağmen, kavramların kuşattıkları anlam alanı ve birbirleri ile ayrıştıkları yönler hakkında yaygın bir kafa karışıklığı vardır. Söz konusu kafa karışıklığı birçok akademik eserde bile kavramların yerli yersiz, anlamlarına uygun olmayan bağlamlarda yahut birbirlerinin yerine kullanılması gibi karmaşık durumları ortaya çıkarmaktadır. Bu çalışmanın amacı "modernite" (modernlik) ve "modernizm" kavramlarının anlam alanlarının farklılaştıkları ve kesiştikleri noktaları açık bir biçimde göstermenin yanı sıra ortaya çıktıkları tarihsel ve toplumsal bağlama işaret ederek, Batı-içi bir tartışma olarak özelliklerini açıklamaya çalışmaktır. Çalışmada, bu kavramlar çerçevesinde ortaya çıkan başlıca tartışmalar karşılaştırmalı analiz yöntemi ile incelenmiş, modernitenin, 19. yüzyıl sonrası Batı'nın tarihsel hikayesi olarak; modernizmin ise modernitenin kültürü olarak anlaşılabileceği ortaya konmuştur.

Anahtar Kelimeler: Modernite, Modernizm, Aydınlanma, Kapitalizm, Us

\begin{abstract}
Although the concepts of modernity and modernism are frequently encountered in both social science literature and everyday life, there is widespread confusion about the semantic domain these concepts encompass and the aspects in which they differ. The confusion in question leads to complex situations such as the improper usage of these concepts in ways that are incompatible with their meanings, or the use of these concepts interchangeably, even in many academic works. The purpose of this study is to demonstrate clearly the semantic domains of the words modernity and modernism, as well as their differences and similarities, and to explain their characteristics as an intraWestern debate by referring to the historical and social context in which they originated. In this study, the main discussions that have arisen within this framework have been assessed using a comparative analysis method, and it has been suggested that modernity could be understood as the post-1 $9^{\text {th }}$ century historical tale of the West, and modernism as the culture of modernity.
\end{abstract}

Keywords: Modernity, Modernism, Enlightenment, Capitalism, Reason

ORC-ID: F. Altun 0000-0001-8139-1469 


\section{Giriş}

Türkiye'de ve dünyada sosyal bilimleri yakından takip eden pek çok okuyucu, zaman zaman ortaya çıkan ve popüler hale gelen meşhur tartışmalardan haberdardır. Belirli zaman aralıklarında disiplini etkisi altına alan ve kendilerine temas etmeden neredeyse hiçbir şeyin tartışılmasına olanak bırakmayan pek çok tartışma, sosyal bilimler literatürü içinde yerini almıştır. Bu tartışmalardan biri de sosyal bilimleri uzunca bir süre meşgul etmiş olan ve hala canlı bir tartışma başlığı olan modernite konusudur.

Bu makale, 20. yüzyıl boyunca yoğun düşünsel mücadelelere neden olan modernite tartışmasının Türk okuyucusu açısından anlamını ve bağlamını ortaya çıkarmaya çalışmak, söz konusu tartışma ile bağlantılı olarak "modernite (modernlik)" ve "modernizm" şeklinde karşımıza çıkan kavramların bağlamlarına ve kapsadıkları anlam alanına dair bir sondaj çalışması yapmak üzere kaleme alınmıştır.

Tartışmanın üzerinde yükseldiği kavramların nitelikli ve anlaşılır tariflerinin yapılması makaleden murad edilen faydanın ortaya çıkması için elzemdir. Zira makalemize konu kavramlar, birbirleri ile çelişen tanımlardan tutunda günlük kullanımlarında yaygın yanlışlara kadar karmaşık bir anlam alanı içerisinde yer almaktadır. Tanımlardaki çelişki son derece temel noktalardaki görüş farklılıklarından kaynaklanmakta, yanlış kullanımlar ise büyük oranda kavramların birbirlerinin yerine kullanılması veya ikame kavramlar gibi tüketilmeleri şeklinde ortaya çıkmaktadır. Türkiye'de sosyal bilim mahfillerini uzunca bir süredir meşgul etmesine rağmen söz konusu kavram kargaşası bilimsel eserlerde/söylevlerde dahi sıklıkla karşımıza çıkmaktadır. ${ }^{1}$

Bu çerçevede karşımıza çıkan ilk kavramsal meydan okuma tartışmaya rengini veren "modernite" ve "modernizm" terimlerindeki kavramsal geçişkenliktir. Söz konusu kavramların bilimsel yayınlarda dahi sıklıkla birbirlerinin yerine kullanıldığı görülmektedir. Hal böyle olunca post-modernite ve devamındaki tartışmalar da pek çok okuyucu için karmaşık bir görünüm arz etmektedir. Zira "modernite ve modernizm" eksenindeki kavramsal geçişkenlik, sonraki tartışmaları da anlamayı güçleştirmektedir. Çünkü başta post-modernite tartışması olmak üzere modernite ile ilişkili bütün tartışmaların adeta modüler bir yapıda olduğu ve her bir tartışmanın sonraki tartışmanın

\footnotetext{
1 Söz konusu kavram kargaşasına bir örnek olarak bkz. Hasan Bülent Kahraman, Türk Şiiri, Modernizm, Şiir, İstanbul: Büke Yayınları, 2000, s. 10. Burada Kahraman modernizm kavramını hem modernizmi hem de moderniteyi içerecek şekilde kullanmaktadır. Ancak bundan daha da ilgi çekici olan, kavramsal kargaşayı aşma amacıyla "Türk modernizması" şeklinde bir kavramsallaştırma yapılmış olmasıdır. Bu kavramla tam olarak neyin kastedildiği açık değildir.
} 
zeminini oluşturduğu görülmektedir. Adeta akışkan görünen bir zemin üzerinde sayısız bilim insanının katkıları ile neredeyse devasa bir külliyata dönüşen tartışmalar bina edilmektedir ve pek çok okuyucu için bu akışkan kavramsal ekosisteme uyum sağlamak kolay değildir. Peki, akademik olarak bu denli önemli bir tartışmada, tanımlar düzeyinde bile yaygın bir bilimsel ittifakın oluşmaması, akışkan zeminin verili olarak kabul edilmesi neyle alakalı olabilir?

Bu soruya verilebilecek iki cevaptan biri tartışmanın hacmi, diğeri ise mahiyeti ile ilgilidir. Dışarıdan bakan pek çok okuyucu için devasa bir külliyata dönüşen tartışmanın hacmi cesaret kırıcı olabilmekte, alanda uzun zaman geçirmemiş olanların tartışma hakkından kısa sürede vazgeçerek işi uzmanlara havale etmelerine sebep olmaktadır. Bu durum kavramların etrafındaki sis bulutunu adeta verili bir durum haline dönüştürmektedir. Ancak bize göre bu tartışmaya özelliklerini kazandıran; hacim keyfiyetinden ziyade tartışmanın mahiyeti ile ilgilidir.

Modernite ve modernizm bağlamında yürüyen tartışma, Batı'nın 19. yüzyılda görünür hale gelen ve etkileri günümüzde hala devam eden zihniyet değişiminin ve buna bağlı deneyiminin bir sonucudur ve bütün özelliklerini Batı'nın bu tecrübeyi yaşayış biçiminden ve onunla hesaplaşmasından almaktadır. Batı, 19. yüzyıldan itibaren büyük bir değişim-dönüşüm süreci içine girmiş, toplumsal yapısı ve kurumları bütünüyle farklılaşmıştır. Ancak bu farklılaşma kolay olmamış, yaşanan sert geçiş Batı içinde pek çok sorunu beraberinde getirmiş̧tir. Batı, sosyoloji ilmini de yardıma çağırarak (Bottomore, 2000) bu keskin tarihsel virajı almış ve yaşadığı tecrübeye geriye dönük olarak bir ad vermiştir: Modernite (modernlik).

Batı'nın, Batılı sosyologlar eliyle yaşadığı tecrübeye verdiği bu ad, onun her şeyden önce peşinden gittiği "Biz ne yaşadık?" sorusuna, nispeten tutarlı bir çerçeve sağlamış olması açısından önemlidir. Bu süreçte Batılı düşünürlerin kendi varlıklarına ve toplumlarına dönük farkındalıkları ve kendi deneyimlerine bir ad vererek onu insanlık tecrübesi içinde farklı bir yere koyma motivasyonları son derece belirleyici olmuştur. Sınırları modernite (modernlik) olarak çizilen ve tarihsel olarak farklılaştırılan bu deneyimin mahiyetine, toplumsal, siyasal ve tarihsel özelliklerine dair bütün konuşmalar modernite tartışması olarak ortaya çıkmıştır. Bu tartışmanın içinde moderniteyi tanımlamaya, tasvir etmeye dönük çabalar, moderniteyi ortaya çıkaran zihniyete ve tarihsel gelişmelere dair analizler, modernitenin açmazlarına, ürettiği sorunlara dair belirlemeler ve modernitenin ürettiği toplumsal, siyasal, ekonomik sorunlar için önerilen pek çok çözüm, hatırı sayılır miktarda felsefi temellendirme çabası, sistem kurmaya dönük kapsamlı mikro tartışmalar ve tarihi yeniden yorumlayan meta anlatılar yer almıştır. Modernizm ise 
modernite olarak adlandırılan süreci takiben ortaya çıkmış, esasen düşüncenin aşkın olandan ayrılması ile estetik bakışın dünyaya ve burjuva toplumunun kendisine yönelmesi ile ilişkili olarak ürünler ortaya koymuş, ağırlıklı olarak sanatsal bir çerçevedir. Modernitenin kültürünü inşa eden modernizm söz konusu olduğunda, bütün sanat yapıtlarının, eserlerin ve akımların ortak özelliğinin, bir övgü yahut yergi şartına bağlanmaksızın "modern durum" konulu üretimler şeklinde ortaya çıktığını söylemek yerinde olacaktır.

Batı bağlamında uzun ve sancılı bir düşünsel üretim neticesinde ortaya çıkan bu tartışma Batı dışı dünya tarafından da ilgiyle takip edilmiştir. Türkiye'de de takip edilen bu tartışma içinden üretilen kavramların sosyal bilim yazınımızda sıklıkla karşımıza çıktığı ve düşünce dünyamızı etkilediği görülmektedir. Ancak Batı bağlamı ile farklılaşan bağlamımız nedeniyle, Batı içinde anlamlı olan kavram setinin bizim tartışmalarımıza her zaman tam olarak oturmadığı ve düşünce dünyamızı belli oranda kavram kargaşası ile karşı karşıya getirdiği görülmektedir. Bu makale, söz konusu kavram kargaşasının izale edilmesi adına mütevazı bir katkı yapmak ve Batı ile farkılaşan bağlamımıza dikkat çekmek amacıyla kaleme alınmıştır. Bu amaca matuf olarak doküman analizi ve karşılaştırmalı analiz yöntemlerine başvurulmuş, ağırlıklı olarak birincil kaynaklardan ve gerekli durumlarda da ikincil kaynaklardan faydalanılmıştır. Literatür taraması esnasında modernite (modernlik) ve modernizm hakkında yapılan başlıca tartışmalara ve önemli kuramcıların/düşünürlerin bu bağlamdaki çalışmalarına odaklanılarak, karşılaştırmalı bir değerlendirme yapılmıştır.

Makale iki bölümden oluşmaktadır. "19. Yüzyıl Sonrası Batı Zemini: Modernite” başlığını taşıyan birinci bölümde; modernite olgusunu ortaya çıkaran tarihsel koşullar ortaya konmaya çalışılmıştır. Bu çerçevede insanın doğadan ayrışması, makineleşme, ussallaşma, bireyleşme, serbest piyasa ve tüketim toplumun ortaya çıkışına değinilmiş, modernlik sürecinde, Avrupa içi sarsıntıların mahiyeti ortaya konmaya çalışılmıştır. "Modernitenin Kültürü: Modernizm" başlığını taşıyan ikinci bölümde ise; modernitenin ürettiği yaşam tarzı ve buna bağlı olarak ortaya çıkan estetik bakış açısı ve bu bakış açısının yaslandığı felsefi temeller incelenmeye çalışılmıştır. Sanatın burjuva yaşam biçimi ile ilgili hale gelişi ve insan yaşamından ayrışarak, özerk bir karakter kazanması bu bölümde incelenmiş, otonom hale gelen sanatın modernlik projesini nasıl sarstığı açıklanmaya çalışıımıştır. Batı-dışından modernite-modernizm tartışmalarına bakanların yaşadığı kavram kargaşası ve buna ilişkin değerlendirmelere ise sonuç bölümünde yer verilmiştir. 


\section{Yüzyıl Sonrası Batı Zemini: Modernite}

"Modernite" uzun yıllardır konuşulan ve pek çok tanımlama/açıklama, dönemlendirme teşebbü süne konu olmuş bir kavramdır. Bu özelliği, kavramın en az kendisi kadar dikkat çekicidir. Moderniteyi tanımlamaya çalışan düşünürlerin pek çoğu meseleye buradan başlamıştır. Söz konusu düşünürlerden biri olan Jürgen Habermas, "Modernity- An Incomplete Project" adlı makalesinde bu konuyu tartışmıştır. Buna göre; tarihten öğrendiğimiz kadarıyla kadim ve modern tanımlamaları daima mevcut olmuştur. "Modern" terimi ilk kez Roma'yı pagan tarihinden ayrıştırıp, Hristiyanlığı benimsediği güncel durumuna atıf yapmak üzere 5. yüzyılda "modernus" şeklinde kullanılmıştır (Foster, 1987). Bazı yazarlar modernite'yi Rönesans ile sınırlasalar da bu tarihsel olarak çok sınırlı bir bakış açısıdır, çünkü insanlar, kendilerini 12. yüzyılda, 17. yüzyılda yahut kadim zamanlarla ilişkilerinde farklılaşmaya dair ne zaman bir bilinç geliştirseler, modern olarak tanımlamışlardır. Böylece değişen içeriklere rağmen modern terimi en temelde kendisini eskiden yeniye geçiş sürecinin sonucu olarak gören bir bilinç durumu ile karakterize olmaktadır (Foster, 1987).

Anthony Giddens ve Philip W. Sutton'a göre modernite, 18. yüzyıl Avrupa Aydınlanması'ndan 1980'li yılların ortalarına kadar süren ve sekülerleşme, rasyonelleşme, demokratikleşme, bireyselleşme ve bilimsel düşüncenin gelişimi gibi unsurlarla karakterize edilen dönemdir (Giddens \& Sutton, 2018). Madan Sarup da moderniteyi benzer bir biçimde tanımlamakta; Batı'da 18. yüzyılın başlarından itibaren ortaya çıkmış toplumsal, ekonomik, siyasal sistemler kümesine gönderme yapan özetleyici bir terim olarak düşünmektedir. Ona göre modernite, genellikle Rönesans'la birlikte ortaya çıktığı kabul edilen ve çoğunlukla antik dönemle ilişkisinin kurulmasına özen gösterilen bir kavramdır ve özellikle son derece etkili bir konumda bulunan Alman toplum bilim kuramının bakış açısından kaynaklanmaktadır. Buna göre; modernite ilerlemeyi hedef alan ekonomik ve yönetsel ussallaştırmayı, toplumsal dünyanın farklılaşıp ayrışmasını ifade eder. Ayrışma ile anlatılmak istenen, örneğin olgunun değerden, etik alanın kuramsal alanlardan ayrışması türünden ayrışmalardır ve bunları başta Max Weber, Ferdinand Tönnies, Georg Simmel gibi Alman sosyologlar, modern kapitalist sanayi devletine varlık kazandıran süreçler olarak görmektedirler.

\section{Doğa'dan Ayrışma ve Makinenin Insan Yaşamını Belirlemeye Başlaması}

Abel Jeanniere, Batı'nın moderniteye geçiş sürecini açıklarken dört önemli basamaktan bahseder. Devrim olarak nitelendirilen bu dört aşama; bilimsel devrim, siyasal devrim, kültürel devrim, teknik ve endüstriyel devrimdir. Buna göre; bilimsel devrimi başlatan Isaac Newton'dur. Evrensel yerçekimi kanununu keşfeden Newton, doğrudan Tanrı 
tarafından yönetilen bir doğa anlayışından kopularak, kendini düzenleyen doğa anlayışına geçilmesinin ilk adımını atmıştır. Bu anlayışın sonucunda Tanrı'nın istekleri ile şekillenen ve Tanrı'nın ihtişamını yansıtan bir doğa anlayışı terk edilerek, doğanın yasalarının belirlenimciliği anlamına gelen bir gök mekaniğine (Henry, 2016) geçilmiştir. Bu kopuştan önce insan, Tanrı'nın belli bir ölçü ile yarattığı dünyada, kendisini doğalla tanrısal arasında bir aracı olarak görmektedir ve moderniteye geçişle birlikte insanın bu konumu sarsılmıştır. İnsan da artık diğer her şey gibi doğanın bir parçasıdır ve tanrısal/manevi bir yönü bulunmamaktadır. Bundan böyle, fiziksel evren, mekanik olarak düzenlenmiş, determinizme boyun eğen ve insanın yasalarını keşfetmek zorunda olduğu bir evren haline dönüşmüştür.

Her varlığın, temelini kendisinin de ötesinde, gerçekliğin öteki katmanları ile ilişkili olarak algıladığı, doğanın, insana çözmesi için verilmiş "Dünya Kitabı” olarak görüldüğü bir kültürel atmosferden, kainatın dev bir kozmik otomat olarak anlaşıldığı bir kültür dünyasına geçilmiştir. Fritjof Capra, zihin ve madde arasındaki bölünme ve akla üstünlük atfetme ile kendisini ortaya koyan bu evren anlayışının, doğal olayları ve etkileşimleri temel maddi yapıtaşlarına birer birer indirgemek suretiyle birbirinden kopuk nesnelerden kurulu mekanik bir sistem olarak okumayı ve bu kartezyen anlayışa canlıları da dahil etmeyi beraberinde getirdiğini savlar. Bu anlayış içinde canlılar da bağımsız parçalardan oluşan makinelerden ibarettir (Capra, 1992).

Bu mekanistik anlayışın felsefedeki yansıması pozitivizm olmuştur. 19. yüzyıla gelindiğinde üniversitelerdeki bütün disiplinler pozitivist bakış açısının tesiri altına girmiştir. Hukukun nasıl olması gerektiğini değil, nasıl olduğunu öğreten, doğru ve yanlış gibi fikirlerden tamamen bağımsızlaşmış bir hukuk, serbest pazarın değerini savunan ve pazarların hangi yollarla ürün talep ettiğini keşfetmeye hasredilmiş bir iktisat, hastayı kurtarmaktansa doğru teşhis koymaya yahut yanlış bir teşhisi düzeltmeye odaklanan ve organizmada bilinen fiziksel ve kimyasal güçlerden başka faaliyette olan hiçbir gücün olmadığına inanan bir tıp bilimi ve evreni su sızdırmaz bir matematik içine hapsetmeye çalışan, "her şey yalnızca ve yalnızca maddeden ibarettir" diyen bir fizik bilimi ortaya çıkmıştır (Everdell, 2007). Bu mekanistik anlayış hayatın her cephesine sirayet etmiş, akademik disiplinlerde ve yönetim faaliyetlerinde çok iyi bilinen parçalanmaya neden olmuş, doğal çevrenin ayrı ayrı parçalardan meydana gelmiş bir şey olarak algılanması ile sömürüye "rasyonel" bir zemin sağlanmıştır (Capra, 1992).

Jeanniere'e göre siyasal, kültürel ve teknik devrimler bilimsel devrimden türemiştir. Bilimsel devrimin ardından siyasal alanda da bir kopuş yaşanmıştır. Modern demokrasinin önce İngiltere ve Amerika'da, ardından da Fransa'da ortaya çıkması ile bu 
kopuş belirginlik kazanmıştır. Buradaki devrimsel farklılık, demokrasinin öbür yönetimler arasında yalnızca bir yönetim biçimi olmaktan çıkarak, Devlet'in tek rasyonel biçimi olarak algılanır hale gelmesidir. Buna göre; modern devlet ancak demokratik olabilirdi. Bu anlayış, o güne dek geçerli olan iktidar anlayışını alt üst etmiş, Tanrı'dan yahut başka bir kaynaktan alınan iktidar gücünü, ulus olan halkla ilişkilendirmiştir. Meşruiyet, bundan böyle gelenekten, vatana bağlılıktan, soy sop ilişkilerinden değil, "ulus" haline gelmiş halkın onayından geçmektedir. Ancak meşruiyet için bu da yeterli değildir. İktidarın aynı zamanda akla uygun olması gerekmektedir. Bu da yöneticinin, devletin, halkla olan ilişkisini rasyonalite içinde kurmasını ve uygulamasını bir şart olarak ortaya çıkarmıştır. Modern siyasal teori açısından problematik bir alana dönüşen bu anlayış, halkı yol gösterilmesi gereken cahil yığınlar olarak gören ve bu nedenle zaman zaman dayatmacı, tepeden inmeci politikalara yol veren yönetim biçimlerini ortaya çıkarmıştır. Bu da kaynağını halktan alan meşruiyet anlatısına uzun dönemde en fazla zarar veren ve demokrasi teorisini aşındıran yönlerden biri olarak ortaya çıkmıştır.

Jeanniere, siyasal devrimi kültürel devrimin takip ettiğini aktarmaktadır. Buna göre; kültürel devrim, diğer devrimler gibi aniden ortaya çıkmamıştır. Kültürel devrim, yeni fiziksel dünya görüşünün içinde kök salmıştır ve Aydınlanma olarak adlandırılan düşünsel gelenekten beslenmektedir. Düşüncenin laikleşmesi, her alanda tüm ölçütlerin rasyonelleşmesi söz konusudur. Bu da laikliğin kendisini kurumsal dine karşı konumlandırmasına ve dini metinleri seküler biçimde ele almasına neden olmuştur. Bu yönelim, dini metinleri toplumu, tarihi ve evreni anlamak için kullanılan birer rehber olmaktan çıkarıp, diğer metinlerle aynı seviyeye indirmiş ve rasyonel olanın hakimiyetini kabule zorlamıştır. Bu akımın vardığı en uç nokta; toplumsal yaşamın temellerinin yalnızca rasyonel temeller olabileceğinin dayatılması şeklinde olmuştur. Böyle bir kurgu içinde dinin yeri, toplumun temelinde yer almak şeklinde değil, folklorik yahut kültürel bir öğe olarak bir kenarda tutulması şeklinde olmuştur. Bu aşamadan sonra, insanın araştırılması tüm alanlarda merkezileşmiş, ister insanın doğayla ister başka insanlarla ilişkileri söz konusu olsun, bilimsel merakın merkezine insan yerleşmiştir.

Doğa ile ilişki konusunda da fizikçilerin bakış açıları bütünüyle sahiplenilmiştir. Buna göre; doğa artık Tanrı'nın insan için kurduğu bir ev değildir; insan artık özerk ve kendini düzenleyen bir doğanın içinde yaşamamaktadır. Bu nedenle, insanın Doğa'nın yasalarını keşfetmesi ve ona hükmetmesi gerekmektedir. Doğa'ya biçilen bu rolün ve insanın Doğa karşısında hiyerarşik olarak üst konuma çıkarılmasının dolaysız sonucu; Endüstri Devrimi olarak karşımıza çıkmıştır. İnsanın içine doğduğu Doğa'yı fethetmesinin yolu, insan emeğinin soyutlanmasından geçmiş, bunun mümkün olabilmesi için de insan ile doğa arasında aracı konumda olan teknik yapının alanı giderek büyümüş, özerklik 
seviyesine ulaşmıştır. Böylece emek süreci doğrudan üretici insana değil, makineye bağlı hale gelmiştir. Soyutlanan emek, emek süreçlerinin mekanikleşmesini beraberinde getirmiş ve insanın makineleştiği sürecin başlatıcısı olmuştur. Teknik yapının özerkleşmesi ile insanın imalat sürecinin dışına atılması mümkün hale gelmiş ve insanoğlu kendisiyle doğa arasında aracılık yapan teknik alanda, sürecin başlatıcısı olma özelliğini yitirmiştir (Jeanniere, 2018).

Özerkleşen teknik yapı insan yaşamının sınırlarını belirlemeye başlamış, insanı makineye tabi hale getirmiştir. Öyle ki insanoğlu o güne dek deneyimlediği zaman algısını bile değiştirmek zorunda kalmıştır. Oyun ve eğlence ile iç içe geçmiş endüstri öncesi çalışma düzeni, makinelerin merkeziliğinde örgütlenen (Ritzer, 1998) endüstriyel çalışma düzeni ile taban tabana zıt hale gelmiştir. Bu aşamadan sonra dakiklik ödüllendirilmeye, geç kalma para cezası yahut işten çıkarılma ile "ödenmeye", makinelerinin başındaki erkek, kadın, çocuk işçiler yarış halinde çalıştırılmaya başlanmıştır. Zaman, "tasarruf edilen", "harcanan" yahut "israf edilen" bir meta olarak işçiler tarafından "satılır", işverenler tarafından "alınır" olmuştur. Çalışma saati ile boş zamanın kesin sınırlarla birbirinden ayrılmasıyla; insanın doğal yahut şahsi ritimlerinden ziyade makineye tabi oluşuna, bireysel beceriler ya da ifadeden ziyade üretkenliğine vurgu yapılan bir çalışma (Adas, 2001) ve yaşam düzeni hâkim hale gelmiştir.

Bütün bu devrimlerin ortaklaştıkları nokta; insanın doğadan ayrışması, doğayı sırlarını çözebileceği ve böylece kendi menfaatlerine göre manipüle edebileceği sınırsız bir kaynak ve "karşılıksız bir hediye" gibi algılamaya başlaması olmuştur. Bunu başarmak üzere başvurduğu en önemli araç ise akıldır.

\section{Akıl, Birey, Serbest Piyasa: “Doğal Seçilim” ve Sömürü}

Akıl çağı basit bir ilkeden hareket etmiştir; aklın düzeni insanlara istediklerini vermeye muktedirdir. Bundan sonra gelen modernite de aklın kendisinden başka bir yere dayanmaya ihtiyacı olmadığı, bir geleneğe yahut mite yaslanmak zorunda olmadığı (Çiğdem, 1997) ilkesinden hareket ederek aklı, bilgi edinme kaynaklarının en tepesine yerleştirmiştir. Akıl, artık geleneğin ve dinin tahakkümü altında değildir. Her birey aklı kullanma yetisine sahiptir. Aklın özerkliği, bireyin özerkliğini, dinden ve gelenekten özgürleşmesini getirecek ve bireyi her şeyin başlangıç noktasına yerleştirecektir. Burjuvazinin, Kilise ve aristokrasiye karşı aklın özerkliğini savunması tam da bu nedenle gerekli görülmüştür. Bireyin bilgi ve toplum için bir başlangıç noktası olarak değerlendirilişi ile "pazar" ve "mübadele"yi yaratan şartlar da ortaya çıkmıştır. Özerk akıl, 
özerk bireyi inşa etmiş, özerk birey de tabiatı ve toplumu pazarlaştırmıştır (Çiğdem, 1992).

Artık gözeten, kuşatan, seven yahut cezalandıran bir Tanrı yoktur ve böyle bir dünya tasavvuru içinde her şeyin ölçüsü insandır. İnsan neyi, ne kadar uygun görüyorsa, o kadar yapabileceğine inanmaya başlamıştır ve bu anlayış, güçlü olanın seçilimi ilkesini beraberinde getirmiştir. Darwin tarafından açıklanan ve doğada güçlü olanın hayatta kalarak türünü devam ettirdiği, zayıflarınsa yok olduğu bir düzen (Darwin, 1997) varsa, bu insan yaşamı için de geçerli olmalıydı, çünkü doğal durum buydu. Doğaya, doğa dışı, Tanrısal bir güç müdahale edip, insanların birbirleri ve doğa ile olan ilişkileri düzenleme hakkına sahip değildi. Her insan gücü ve kabiliyetleri ölçüsünde ne yapabiliyorsa, onu yapabilirdi. İnsanın yapabileceklerinin önünde doğa dışı, tanrısal bir engel yoktu. İnsan, kendi sınırlarını kendisi koyuyordu. Hümanizm olarak adlandırılan ve insanı kendisinin efendisi sayan felsefi anlayış bu bakış açısını toplumsal ve siyasal alana da taşıyarak yaygınlaştırmıştır. Tüm bu süreçlerin sonunda insanın doğa üzerinde sınırsız bir kullanım hakkı olduğu, gücü ve kabiliyeti olanların doğa üzerinde her türlü tasarrufu yapabileceği düşüncesi tartışma dışına çıkarılmıştır. Önceki kuşakların, kökenini dinlerden alan ve doğayı bütün canlıların ve varlığın ortak hazinesi olarak gören anlayışı tamamen terk edilmiştir. ${ }^{2}$

Insanı kendi efendisi olarak gören anlayışın dolaysız sonuçlarından biri de onu, başka insanların efendisi olarak gören anlayışın ortaya çıkması olmuştur. Sosyal Darwinizm'in etkisiyle gücü ve kabiliyeti yüksek olanların daha zayıf olanları ortadan kaldırması, onları kendi amaçları için kullanmaları, köleleştirmeleri hatta katletmeleri mümkün hale gelmiştir. Yüzyıllar boyunca sanayi üretimine hammadde olmak üzere ormanlar tahrip edilmiş, yeraltı, yerüstü kaynakları talan edilmiş, toprak, hava ve su hızla kirletilmiştir. Bununla birlikte sanayi üretiminde pek çok yerli halk köle olarak çalıştırılmış, emeği ucuzlatmak için her çareye başvurulmuş, kadınlar doğadan tamamen kopartılarak ev içi emekle görevlendirilmiş ve emekleri bütünüyle görünmez hale getirilmiş, emek, bakım, enerji, doğa, para, gıda ve insan yaşamı giderek ucuzlatılarak (Patel\&Moore, 2019) yeni bir sistem inşa edilmiştir. Kapitalizm olarak adlandırılan bu ekonomik kurgu, zihniyeti ve yaşam biçimini dönüştürerek karşımıza modernite olgusu çıkarmıştır.

\footnotetext{
2 Jan Romein'in, "Genel Beşeri Kalıp” olarak Türkçeye çevrilen AMP (Algemeen Menselijk Patroon) Teorisi bu bakış açısına dair dikkate çekici bir teoridir. AMP Teorisi, modernite öncesi toplumların, doğayı, toplumu, insan yaşamını geçicilik üzerine kurgulayan, vahiy ve gelenek eksenindeki bakış açılarının yaygın biçimde benzer olduğunu, modern dönemde bu anlayıştan keskin bir biçimde uzaklaşıldığını, modern durumun tarihsel bir sapma olarak görülebileceğini iddia etmektedir. Bkz. Anton C. Zijderveld, Sahnelik Toplum, Sosyolojinin Yeniden Tanımlanması, çev. Kadir Canatan, İstanbul: Pınar Yayınları, 2007, s. 201-206.
} 


\section{Tarihsel Kaynaklar}

Moderniteyi açıklamaya çalışan düşünürlerin ortaklaştığı noktaların başında, onun belli bir zaman süreci ve coğrafi çıkış noktası ile ilişkili olduğu tespiti gelmektedir. Giddens, bu ilişkiyi kabaca 17. yüzyıl Avrupa'sında başlayıp, sonraları bütün dünyaya yayılan bir "toplumsal yaşam ve örgütlenme biçimi" (Giddens, 1994) olarak açıklar. Habermas da benzer bir noktadan hareket eder ve kavramın işaret ettiği örgütlü akla dikkatimizi çekerek "modernite projesi” kavramsallaştırmasını kullanır. Bu yönüyle Habermas'ın ve modernite üzerine yazan bütün düşünürlerin tarihsel bir kırılmadan, bu kırılmanın Batı ile olan illiyet ilişkisinden, Batı içinde ve dünyanın geri kalanı üzerindeki etkilerinden bahsettikleri ve bu çerçevede büyük bir konuşma başlattıklarını görürüz. Bu konuşmanın merkezinde ise Batı'nın bir askeri, ekonomik ve siyasal güç olarak yükselişi yer almaktadır. Batı'nın yaşadığı bir tecrübe ve onun etrafında şekillenen bir olaylar dizgesi olarak moderniteden bahsedebilmek için ise bakışımızı tarihsel bazı gelişmeleri de içerecek şekilde genişletmemiz gerekmektedir.

Bugün adına modernlik denen olguyu ortaya çıkaran gelişmeler en temelde Kıta Avrupası'nda karşımıza çıkmıştır. Özellikle dönemsel olarak Orta Çağ Avrupası ve bu süreçte kentlerin ortaya çıkışı son derece önemlidir. Bu dönemde, para ekonomisinin ortaya çıkışı ve Avrupa feodalizmini niteleyen bireyselleşmiş köylü ekonomisinin yavaş yavaş geniş bir para ağına ve pazar ilişkilerine dahil edilmesinin feodal toplum yapısını çözerek yeni türde bir ekonomik ilişkiler ağı yarattığı görülmektedir. Leo Huberman'a göre; 11 . yüzyıldan önce gerçek anlamda bir ticari canlılığa sahip olmayan Avrupa, ancak on birinci yüzyılda ticarette büyük adımlar atmış, bu durum Batı Avrupa'da büyük bir değişim yaratmıştır (Patel\&Moore, 2019). Burada bahsi geçen temel değişim faktörü Haçlı seferleridir. Haçlı seferleri, Hristiyanlığın Avrupa'da resmi din olarak kabulünden ve daha da önemlisi Charlemagne'ın, Halife Harun Reşid ile diplomatik ilişkilerde bulunmaya başlamasından sonra Kudüs'e düzenlenen hac kervanlarının, politik ve ekonomik amaçlarla biçim değiştirmesi sonucu ortaya çıkmıştır. Patel ve Moore, 1095'te başlayıp Akdeniz'in doğusundaki zenginlikleri hedef alan ve "Haçlılar" olarak formüle edilen yeni türde askeri/siyasi hareketliliğinin aslında "büyük ölçüde ticarileştirilmiş ve askerileştirilmiş" (Patel\&Moore, 2019) bir organizasyon olduğundan söz ederler. Buna göre yüzeyde dalgalanan din bayrağının altında pek çok farklı amaca sahip insan toplanmıştır. Bunların içinde cennete gitme amacı taşıyanlardan, zengin olma motivasyonu ile yola çıkanlara yahut feodal beylerin zulmünden kaçanlara dek pek çok insan vardır. 
Illk Haçlı seferi asiller, burjuvalar, efendiler, köleler, kadınlar ve çocuklardan oluşan 1.300.000'i aşkın kalabalık bir kitleyi Doğu'ya doğru harekete geçirmiştir. On binlerce savaşçının karadan ve denizden geçerek "kutsal ülkeyi Müslümanlardan kurtarma" ülküsünün peşinde Doğu'ya gitmeleri, yolculuktan geriye dönebilenlerin orada gördükleri garip ve lüks mamullere karşı iştahlarının açılmasına sebep olmuş ve onların talepleri, bu mallar için bir pazar yaratmıştır. Haçlı Seferleri'nin dua edenleri, savaşanları, çalışanları ve çoğalan bir tüccar sınıfını bütün bir kıtaya yayarak Batı Avrupa'yı feodal uykusundan uyandırmış, ticari büyümeyle birlikte şehirler de büyümeye başlamıştır.

Huberman, şehirlerin ilk defa bu süreçte ortaya çıkmadığını ancak bu süreçte, ticaretin teşvikiyle yeni bir hayat tarzı edinen eski şehirlerin farklılaştığına dikkat çekmektedir. Weber, bu farklılaşmayı Orta Çağ Avrupası'nda ortaya çıkan şehirleri, Antik Çağ Avrupası'nda ortaya çıkan şehirlerle kıyaslayarak açıklar. O'na göre; Antik Çağ Avrupası'nın şehirleri politik ve askeri kaygıların şekillendirdiği şehirlerdir. Oysa, Orta Çağ'da yükselişe geçmeye başlayan şehirler "pazar yeri işgaliye" paralarından, ticaret harçlarından ve vergilerden gelir elde etmeyi amaçlayan kurucuların, ekonomik motivasyonları ile ortaya çıkmıştır. Yani artık şehir askeri değil ekonomik bir meseledir. Bahsi geçen farklılaşmanın somut görüngülerinin başında ise loncalar gelmektedir. Şehirde feodal kısıtlamalardan daha az etkilenmek için kurdukları loncalar, tüccarların, feodal beye karşı birlikte hareket ederek, şehirlerde daha rahat gelişmek için ihtiyaçları olan özgürlüğü kazanmalarına hizmet etmiştir.

Tüccarların özgürlükten anladığı bireysel özgürlüğün dışında, istedikleri gibi mal alıp satabilmek, kendi mahkemelerini kurarak kendi sorunlarının, kendi çıkarlarına uygun olarak ele alınmasını temin etmek, vergilerini istedikleri biçimde toplamak ve iş yapmalarının önündeki bütün engelleri ortadan kaldırmaktır. Tüccarlar bu hakları yavaş yavaş ele geçirmişlerdir. Bu süreçte belli başlı hakları lordlardan satın alma çok etkili bir yöntem olarak kullanılmış, bazen de feodal piskoposlarla yahut lordlarla savaşma yoluna gidilmiştir. Süreç içinde kentlerde denetimi eline alan tüccar sınıfı, yeni bir iktidar odağı haline gelmiştir.

O güne dek Avrupa'da hâkim olan toplumsal yapı üçlü bir hiyerarşiye yaslanmaktadır. Ruhbanlar ve soylular yönetici sınıfı oluştururken geri kalan halk yığınları tiers état (üçüncü sınıf) olarak anılmıştır. Ticaret ile yavaş yavaş zenginleşmeye başlayan, son derece dinamik bir karakter sergileyen ve sonraları burjuvazi olarak anılacak olan yeni sınıf, ekonominin üretici tarafından değil, tüccar tarafından yönlendirilmeye başlaması ile beraber Avrupa'da toplumsal sistemi, kentlerin karakterini ve devlet aygıtını 
kökünden değiştirmiştir. Ernst Bloch, tüccarların ekonomik sistemdeki güçlerine bağlı olarak yeni bir hukuk sistemi için baskı oluşturduklarını, tüccarların küçük bir yer işgal ettikleri eski ekonomik sistemin üzerinde oluşmuş bulunan eski hukuk sisteminin yetersiz kaldığını, uygulamaya yönelik isteklerinin ve zihniyetlerinin, onları hukuk sisteminin içine yeni bir oluşturucu unsur olarak katılmaya zorladığını, bunun da Avrupa'da derinlemesine bir değişim sürecini başlattığını söyler (Altun, 2018). Korkut Tuna'ya göre bu değişim sürecinin sonunda burjuvazi, eski ekonomik sistemde şehrin nüfusuna dışarıdan katılan bir unsur olmaktan çıkıp, şehirleri kurum ve yasaları ile kendisine göre düzenleyen egemen bir unsur haline gelmiştir (Altun, 2018). Bloch'un ve Tuna'nın söz ettiği bu değişimde, burjuvaların uzun mesafeli ticaretin sağladığı imkanların ve zenginlik birikiminin farkına vararak devleti de bunu kolaylaştıracak şekilde dizayn etme istekleri başat rol oynamıştır.

Bu süreç "uzun mesafeli ticaret ve devlet maliyesinden kaynaklanan sermaye birikimi, güçler dengesinin yönetimi, savaşların ticarileşmesi ve yerleşik diplomasinin gelişmesi" ile el ele gitmiş, servet ve iktidarın başta Kuzey-italyan kent devletlerini yöneten oligarşilerin elinde olağanüstü bir biçimde yoğunlaşmasını sağlayarak, yeni bir dönemi başlatmıştır. Bu yeni dönemin tarihteki ilk belirgin temsilcisi İtalyan kent-devletleri, küçük bir toprağa sahip güçlerin bile toprak ve uyruklar edinmek yerine tek taraflı bir biçimde servetin birikimiyle, büyük güç depoları haline gelebileceğini kanıtlamışlardır. Bu aşamadan sonra "zenginlik düşüncesi" tüm Avrupa'da "güç düşüncesi"nin odağı haline gelmiştir.

Yukarıda zikredilenlerle birlikte, başta Venedik olmak üzere, İtalyan şehir devletlerinin İslam alemiyle ticari münasebetler kurması, Ahmet Tabakoğlu'nun feodal çerçevenin parçalanması dediği süreci başlatmıştır (Altun, 2018). Bahsi geçen ticari faaliyetler feodalizmin yıkılışının ve kapitalizmin ilk habercisi olup, korsanlık faaliyetleri ile iç içe geçmiş durumdadır. Haydutluk, Avrupalı denizciler için, özellikle düşük maliyetli oluşundan dolayı, önemli bir kazanç kapısı olarak görülmüş; kapitalizm, emperyalizmle omuz omuza tarih sahnesine çıkmıştır. Burjuvazi, kullandığı emperyalist yöntemlerle önemli bir sermaye birikimi sağlarken, oluşan bu sermaye mali işlemlere aktarılmış ve özellikle Yahudilerin ve kilisenin elinde temerküz etmiştir. Kapitalizmin, Orta Çağ'ın ikinci yarısını kapsayan başlangıç safhasında, Batı kültürü temel belirleyici olmuştur. Buna ek olarak Hristiyanlığın faiz yasağı gibi ilkelerinin tekrar yorumlanarak kapitalizme alan açması yahut yanlış kadercilik anlayışı, kapitalizmin gelişmesinde yardımcı bir faktör olarak ortaya çıkmıştır. Bunun yanında sınırsız ferdi mülkiyeti tanıyan Roma hukuku ile akılcı ve uygulamacı yanı ağır basan Yunan düşüncesi bu gidişata eşlik eden 
düşünsel öğeler olarak ortaya çıkmış, Avrupa düşüncesi de tedrici olarak değişmeye başlamıştır. Pazar ekonomisiyle beslenen yeni siyasal düzen, yaşama ve mülkiyet hakkına dayanan insan hakları felsefesiyle beslenen yeni bir düşünsel düzene hayat vermiş, bu yeni ortamın kazananı ise burjuvazi olmuştur (Altun, 2018).

Bütün bu gelişmelerin başlangıç noktasında bulunan sermaye birikimi modernite olgusunun anlaşılması için en merkezi gelişmedir. Zira pek çok araştırmacının da tespit ettiği gibi Batı'nın elde ettiği sermaye birikimi olmasaydı, kapitalizmin ortaya çıkışı dolayısıyla modernite dediğimiz olgu mümkün olmayacaktı. Bu tespiti yapan araştırmacılardan biri olan Landes, dikkatimizi Batı'nın sermaye biriktirmek için kullandığı bazı spesifik kaynaklara çekmektedir. Bunlar; İspanya'nın Gırnata işgali, Afrika seferleri ve sömürgelerinden elde ettiği yağmanın yanı sıra diğer Avrupalı ülkelerin İspanyol sömürge tekeline karşı yürüttükleri kaçakçılık ve her birinin korsanlıktan elde ettikleri yağma, fiyatların uzak mesafeden kaynaklanan geçici dengesizliğine dayanan büyük ölçekli ticaret, koloni bölgelerinin kölelik, zorla çalıştırma ya da yarı feodal metotlarla sömürülmesi ve Avrupa'nın iktisadi-siyasi olarak gelişmiş kısımlarının menfaati için dünyanın Batı ve Orta Avrupa dışında kalan kısımlarından ticaret ve yağma karıla elde edilen zenginliktir (Landes, 1995).

Batı'nın bu kaynaklara erişim yolunda attığı en önemli adım gemicilik teknolojisindeki ilerlemedir. 15. ve 16. yüzyıllarda denizcilik teknolojisindeki ilerleme ve yaptığı dayanıklı gemilerle okyanusları aşmayı başaran Avrupa, Asya ve Afrika ile doğrudan ticaret yapmaya ve Amerika'nın ve başka uzak kıtaların doğal kaynaklarını ve maden zenginliğini kendi kullanımı için gayrimeşru şekilde toplamaya başlamıştır (Arnold, 2001).

Batı, bu zenginlik yoluyla giderek büyük bir askeri ve ekonomik güç haline gelmiş, bu güce yaslanarak büyük siyasal başarılar elde etmiştir. Özellikle I. Dünya Savaşı ve Osmanlı İmparatorluğu'nun parçalanması sonrasında Doğu'da, Batı menşeli kapitalist yayılmacılığa karşı durabilecek örgütlü bir güç kalmamıştır. Bu aşamadan sonra emperyalizmle iç içe geçen kapitalizmin dünya üzerinde sirayet etmediği pek az coğrafya kalmış (See, 2001), emperyalizm ulaştığı topraklarda yerel insan toplulukları üzerinde katliamlar, tarifsiz acılar, yerel kültürlerin geri döndürülemez şekilde tahribatı gibi rakamlara sığmayacak denli büyük yıkımlara sebep olarak ilerleyişini sürdürmüştür (Nadel \& Curits, 1966). Öyle ki Avrupa dışı dünya üzerindeki Avrupa idaresinin küçülmeye başladığı bir dönem olan 1930'da bile dünya küresinin \%84'ü Avrupalı beyaz ulusların kontrolündedir. Bugün Birleşmiş Milletler toplantılarında söz alanların ezici 
çoğunluğu, geçmişte Ingiltere, Fransa, Hollanda, Belçika ve Amerika Birleşik Devletleri'nin sömürgeleri olan ülkeleri temsil etmektedirler (Winks, 1969).

\section{Avrupa Içi Sarsıntılar: Cemaatten Cemiyete Geçiş ve Yeni Düzen}

Batı kaynaklı bu güç dinamiği pek tabi ki ilk etkilerini Batı toplumlarında hissettirmeye başlamıştır. Dışarıdan bakanlar açısından müthiş bir gelişme/ilerleme ve Batı içinde söz konusu ilişkileri örgütleyen kesimler açısından büyük bir kazanç olarak görünen gelişmeler, sıradan bir Avrupalı için; en temelde Orta Çağ Avrupa kurumlarının çökmesinden ibarettir (Delanty, 2015). Bu yönüyle yaşanan değişim esasında bir metamorfozdur ve yeni sisteme geçiş Avrupa için tahammülü zor sarsıntılara neden olmuştur. Batı'da iktidar erki, bir yandan tarihsel ve siyasal bir başarı hikayesi yazmaya çalışırken diğer yandan da toplumsal ve siyasal yapıda ortaya çıkan bu ağır yan etkilerle ve semptomlarla başa çıkmaya çalışmıştır.

Bu yan etkilerin başında dönemin en önemli toplumsal değişim dinamiği olarak temayüz eden toplulukçu yaşam kodlarının çözülerek yerine bireyci yaşam kodlarının geçmeye başlaması gelmektedir. Bu geçiş esasen o güne dek bilinen yaşam biçiminin terk edilip yerine başka, "yeni" bir şey koymaya başlanması ile ilişkilidir. Fransız Devrimi'nin ve Sanayi devrimlerinin tetiklediği bu süreci Marx; feodalizmden kapitalizme geçiş, Alexis de Tocqueville; aristokratik toplumdan, demokratik topluma geçiş, Durkheim; mekanik dayanışmadan, organik dayanışmaya geçiş, Weber; geleneksel olandan ussal-bürokratik olana geçiş, Arthur Schopenhauer; algılama olarak dünyadan, irade olarak dünyaya geçiş, Herbert Spencer; homojenden, heterojene geçiş, Wilhelm Wundt; basit iradeden düşünülmüş iradeye geçiş gibi karşıtıklar içinde açıklamaya çalışmışlardır. Hatta daha sonraları Amerikalı sosyolog Charles H. Cooley; birincil gruplar-ikincil gruplar ayrımını yaptığında yahut Karl Popper'ın açık toplum-kapalı toplum ayrımında, hasılı bugün artık yadsınmaksızın kullanılan geleneksel-modern, kır-kent, tarım-sanayi, az gelişmişgelişmiş ayrımlarında hep bu düalist bakış açısının izleri karşımıza çıkmaktadır (Ünsaldı, 2019).

Söz konusu düalist açıklama biçimleri içinde sosyoloji tarihi içinde en fazla kendisine yer edinen Alman sosyolog Ferdinand Tönnies'in ${ }^{3}$ Cemaat'ten (Gemeinschaft), Cemiyet'e

\footnotetext{
3 Tönnies'e göre cemiyet muhtemel ve cari hizmetler ile bu hizmetlerin takası anlamında bir karşılıklı bağımlılığa dayanır. Bu da ilişkileri görünür kılar. Sınırları ve kuralları belirgin biçimde inşa eder. Buna karşılık cemaat kan bağı ile oluşmuş ve her şeyden önce kendisini sözel olarak ve yardımlaşma ile ifade eden fiziki bir ilişkidir. Burada temel ayrım rasyonel irade ile doğal irade arasındadır. Rasyonel irade cemiyet (Gesel/schaft) ile tabii irade ise cemaat (Gemeinschaft) ile ilişkilidir.
} 
(Gesellschaft) geçiş formülasyonudur (Parsons vd., 1961). Buna göre; toplumlar biri diğerini izleyen gelişmelerden oluşan doğrusal bir gelişim çizgisinde ilerlerler. Bu gelişim çizgisi topluluktan (cemaatten), topluma (cemiyete) doğrudur. Cemaatler daima cemiyet olma eğilimi gösterirler ve bu eğilim er geç gerçekleşir. Geri çevrilemez bu gelişme dinamiğine göre bir defa cemiyet haline dönüşmüş bir insan topluluğu, bir daha cemaat haline dönüşemez. Toplum olma yolundaki gelişme seyri içinde insanlar arasındaki dayanışma duyguları kaybolur, toplulukçu yaşayış bütünüyle değerini yitirir, topluluk küçük çıkar kümeleri şeklinde parçalanır (Freyer, 2012).

Tönnies'in mufassal biçimde açıkladığı bu parçalanmanın sonucunda Avrupa'da insan yaşamı, devlet aygıtı ve sosyal doku dramatik bir dönüşüm geçirmiştir. Bu değişim Aydınlamacı düşünürlerin ancient regime (eski düzen) olarak atıf yaptıkları Orta Çağ Avrupa düzeni ve kurumlarının bütünüyle terk edilip, bambaşka bir düzene geçilmesi ve yeni bir çağın başlaması olarak görülmüştür. Yeni düzen, en özet haliyle, toplumsal yaşamda aristokrasinin yerini burjuvazinin alması, üretim biçimi olarak toprağa dayalı üretim ilişkilerinden kitlesel üretime geçilmesi, Kilise yerine Antik Yunan felsefesine yaslanan bir siyaset felsefesinin ve insan haklarına dayalı bir ontolojinin benimsenmesi ve modern ulus devletin ortaya çıkması ile belirginleşen bir formasyondur. Büyüyen şehirler, insan zihnindeki toplulukçu kodların ve insanın emeği ile bağ kurmasını sağlayan devamlılığın aşınması, toplumsal yaşamda küçük toplulukların giderek parçalara ayrılması ve nihayet atomize hale gelmesi söz konusudur.

Toplulukçu yaşam, yerini bireysel yaşama bırakmaya başladıkça aileler de giderek küçülmüştür. Geniş ailelerin yerini çekirdek aileler alırken insanlar da bir topluluğun parçası olmayı giderek daha az önemser, gelenek, din, kültür gibi değerlerin sınırlayıcı topoğrafyasında seyahat etmekten kaçınır hale gelmişlerdir. Sonraki yıllarda bireycilik olarak adlandırılacak bu eğilimin sonucu ise yalnızlaşmadır. Kentler bazen milyonları bulan nüfusları ile bu yalnızlığın bunaltıcı hale büründüğü yerler haline gelmiş, yalnızlığa eşlik eden derin anlam kaybı ve Weber'in tabiriyle "büyünün bozulması" insanlık için başlı başına bir imtihan konusu haline dönüşmüştür. Çocuk işçiliğinin ortaya çıkışı, sermayenin daha önce hiç görülmemiş biçimde temerküzü, emeğin sömürülmesi ve buna karşı gelişen sendikal hareketler (Bellamy, 2020), sınıf çatışmaları, yoksulluk, manevi sarsıntılar, kontrolden çıkan suç oranları, kentleşme, eğitim sorunları ve kadınların durumu, sosyal dokudaki bu parçalanmanın ürettiği en görünür sorunlardır. Bu gelişmeleri takip eden ve aslında birer bölüşüm kavgası olan iki Dünya Savaşı, 
benzerlerine daha sonra pek çok defa rastlanacak olan 1929 Ekonomik Buhranı, kapitalist yayılmanın karşı karşıya kaldığı daha da büyük meydan okumalar olmuştur. Bu büyük değişim, dönüşüm dalgasının en yoğunlaştığı dönem; 18. yüzyılın sonu ve 19. yüzyıl başı olarak tarihlenmektedir. Bu dönem, yukarıda sayılan sarsıntılar kadar göz kamaştırıcı teknik gelişmelerin de çağıdır. Kitlesel üretim geniş insan topluluklarını, ihtiyaçların ezici baskısından kurtarmış görünmektedir. Tüketim giderek en önemli insan faaliyeti haline dönüşmüştür. İnsan yaşamı uzamış, hastalıklara hızla çareler bulunmaya başlamış, gelişen tarım teknolojileri sayesinde insanoğlu tarihsel açlık sınamasında kendisini daha önce hissetmediği kadar güvende hissetmeye başlamıştır. Bu atmosfer insanların yaşadıkları çağa dönük tutkulu bir algı geliştirmelerine sebep olmuştur. İlerlemenin ve gelişimin baş döndürücü yapısı bütün yan etkileri silikleştiren bir hal almış ve yeni çağa övgü 20. yüzyılın ortalarına kadar yaygın bir bakış açısı olarak devam etmiştir (Altun, 2020).

O dönem Avrupası'nda böylesine büyük bir başkalaşımı yorumlamak başlı başına bir mesele haline gelmiş ve sosyolojinin Kıta Avrupası'nda ortaya çıkışı bütünüyle bu atmosferle bağlantılı olarak gerçekleşmiştir. Henri de Saint-Simon, Auguste Comte, Marx ve Spencer gibi ilk sosyologlar, başlangıcından itibaren tarih felsefesi ve psikoloji ile dirsek temasında kalarak kendi devirlerine rengini veren toplumsal ve siyasal devrimleri açıklamaya çalışmışlar ve sonraki yıllarda da bu çabalar artarak devam etmiştir (Bottomore, 2015). Batı-içi sarsıntılara anlam verme ve açıklama çabası, ortaya çıkan

\footnotetext{
4 Kapitalizm 1929'dan sonra da ekonomik buhranlar yaratmaya devam etmiştir. Bu buhranların ortaya çıkmasında kapitalist ekonomik formasyonun ürettiği eşitsiz bölüşüm etkili olmuştur ve bölüşüm krizi giderek derinleşmektedir. Kuruluşundan bu yana kapitalist bir ülke olan ABD, kapitalist ekonomik formasyonun ürettiği bölüşüm krizini takip etmek için önemli bir örnektir. Buna göre; ABD'de 30 yıl kadar önce, en yüksek gelire sahip \%1'lik kesim gelirin sadece \%12'sini elde etmekteydi. Bu eşitsizlik seviyesi bile kabul edilemez olmalıyken, o günden bu yana aradaki uçurum önemli bir ölçüde artmıştır. Öyle ki, 2007'de en zengin \%1'lik kesimin vergi sonrası kişi başı yıllık ortalama geliri 1.300.000 \$ seviyesine ulaşırken en yoksul \%20'lik dilimde yer alanların vergi sonrası ortalama geliri sadece $17.800 \$$ seviyesinde kalmıştır. En zengin \%1'lik kesim bir haftada en yoksul \%5'lik kesimin bir yılda kazandığından \%40 daha fazla kazanmaktır; en zengin binde birlik kesimin bir günde kazandığı para ise neredeyse en alt \%90’lık kesimin bir yılda kazandığı paraya eşittir. Dahası, en zengin \%20'lik kesimin vergi sonrası geliri, geri kalan \%80'ik grubun toplam gelirinden daha fazladır. Bu korkunç eşitsizliğe rağmen, 2008 krizinden sonra Amerika'da yaratılan ilave gelirin \%93'üne en zengin \%1'lik kesim sahip olmuştur. Amerikalı yoksul ve orta gelirli insanların birikimleri hızla erirken, CEO'lar kendi yüksek maaşlarını muhafaza etmekte başarılı olmuşlardır. 2008'deki küçük bir düşüşten sonra, 2010 yılında yıllık CEO kazancının ortalama bir işçinin maaşına oranı kriz öncesi seviyesine ulaşmıştır: 243'e 1. Kapitalist sistemin adeta tamamlayıcı bir parçası olan sistematik eşitsizlik hakkında daha fazla bilgi için bkz. Stiglitz, Joseph E., Eşitsizliğin Bedeli, Bugünün Bölünmüş Toplumu Geleceğimizi Nasıl Tehlikeye Atıyor?, çev. Ozan İşler, İstanbul: İletişim Yayınları, 2014.
} 
sorunlar karşısında üretilen çözümler, eş zamanlı olarak elde edilen fırsatların düzenlenmesi ve yeni sistemin inşa edilmesine dair bütün bir tecrübe, Batılı sosyologlar tarafından retrospektif olarak "modernite" (modernlik) olarak adlandırılmıştır.

\section{Modernitenin Kültürü: Modernizm}

Sarup'a göre Modernizm, yüzyıl dönümünde ortaya çıkmış, yakın dönemlere gelinceye dek çeşitli sanat dallarını ağırığını koymuş sanat hareketi ile birlikte anılan özgül bir kültürel ya da estetik biçemler dağarıyla yakından ilişkilidir. Modernizm, klasisizme yönelik bilinçli bir karşı çıkış olarak ortaya çıkmıştır. Deneyimin, deneyerek yaşamanın önemini vurgulamış, yüzeydeki görünüşün altındaki hakikati, içteki doğruluğu bulmayı amaçlamıştır. Edebiyatta James Joyce, William Butler Yeats, Marcel Proust, Franz Kafka; şiirde T. S. Elliot, Ezra Pound; tiyatroda August Strindberg, Luigi Pirandello; resimde Paul Cezanne, Pablo Picasso, Henri Matisse'e ek olarak "Dışavurumcu”, "Gelecekçi”, "Dadacı", "Gerçeküstücü" hareketler; müzikte Arnold Schoenberg, Alban Berg, modernizmin temsilcileri olarak ortaya çıkmıştır. H. Bülent Kahraman'a göre ise modernizm; insanların kendi iradelerinden başka her türlü aşkın otoriteyi reddederek özgürlüklerinin önüne yine kendilerinin koydukları engelleri aşma kararlılığı ve kişisel özgürlükle bir arada yaşamanın gereklerinin birbirlerini kısıtladığı değil, zenginleştirdiği bir toplum, daha doğrusu bir dünya yaratma hayalidir (Ünsaldı \& Geçgin, 2019).

Köklerini Rönesans ve Aydınlanma'da bulan bu türden yaygın görüşlere Scott Lash, temelden bir eleştiri getirmekte ve modernite kavramsallaştırmasının yerine artık modernizmin geçmesi gerektiğini savunmaktadır. Bunu temellendirirken modernizm ile sadece günümüz sanatlarının değil, aynı zamanda günümüz toplumsal pratiklerinin de anlaşılabileceğini, çünkü modernizmin, modernitenin temel varsayımlarından bir temel bir kopuşa işaret ettiğini savlamaktadır. Ona göre; günümüz görüngülerinin Rönesans ve Aydınlanmanın modernitesinden ziyade 19. yüzyılın sonlarında ve 20. yüzyılın başlarında başlatılan modernizm ile çok daha fazla ortak yönü vardır. Lash, modernizmi yalnızca Aydınlanma rasyonalitesinin zayıflatılması olarak değil, bununla eşanlı olarak Aydınlanma rasyonalitesinin tözsel rasyonaliteye dönüşerek derinleşmesi ve tüm toplumsal katmanlara sirayet etmesi olarak anlamaktadır. Lash, ayrıca Weber'e atıfla; modernizmin sadece kültürel dünya ile sınırlı bir mesele olmadığını, modernleşmenin ethos'unun 20. yüzyılın hukuk ve siyasetine dek uzanmış olduğunu iddia eder (Küçük, 2018).

Lash'ın son derece dikkate değer bu açıklama biçimi, modernite kavramsallaştırmasının günümüzde artık yetersiz hale geldiği, özellikle 19. yüzyıl sonrasını tanımlamak için yeni 
yahut daha kapsayıcı bir kavrama ihtiyaç olduğu şeklinde yorumlanabilir. Ne var ki modernizm kavramını modernitenin yerine kullanma isteği de benzer bir eksikliği bu kez geriye dönük taşıma ihtimali ile malüldür. Zira modernizm, modernite olgusundan kronolojik olarak sonra ortaya çıkmıştır ve esasen modern durum üzerine yapılan bütün konuşmaları kapsayıcı niteliktedir. Modernitenin kronolojik olarak kendisinden sonra ortaya çıkmış, üstelik kendisi ile nedensellik ilişkisi bulunan bir kavramla açıklanamayacağı açıktır. Bu, ayakları açıkta bırakacak kadar küçük bir yorganı ayakları kapatacak şekilde aşağı çektikten sonra açıkta kalan gövdeyi görmezden gelmeye benzemektedir. Bu nedenle kavramsal olarak "modernite" (modernlik) ile "modernizm"i birbirinde ayrı kullanmaya, kronolojik sıra ve nedensellik ilişkisi içinde kavramların kullanımlarına sadık kalmaya devam edeceğiz.

Buradan hareketle modernizmi daha geniş bir biçimde tanımladığımızda; genellikle 16. ve 17. yüzyıllarda temellerinin atıldığı varsayılan "moderniteye" karşılık; "modernizm"in sanatlarda, 19. yüzyılın sonunda başlayan bir paradigma değişikliği olarak kabul edildiği görülür (Küçük, 2018). Bu anlamda modernizm, modernitenin verili dünyasında ortaya çıkan, modern durumun sanattaki izdüşümünden oluşan bir estetik yönelimdir. Modernlik zemini, bu estetik yönelimin üzerinde yeşerdiği topraktır. Bu yönelişi ortaya çıkaran sanatçılar, modernitenin kendine özgü dünya görüşü ve kültürü ile çeşitli düzeylerde hem ilişki içinde olmuşlar hem de onları inşa etmişlerdir. Bu yönüyle modernizm, kapitalist üretim ilişkilerinin ve kapitalist yayılmacılığın doğası ile karakterize olarak değişen dünyaya, sanatçıların verdiği cevap şeklinde de okunabilir.

Bu dünya, yukarıda bahsedilen eşi benzeri görülmemiş bir inşanın, o güne dek bilinen her şeyin geride bırakılışının görünür hale geldiği bir dünyadır. Bu dönüşümün akışına kapılan geniş kitleler açısından, bu dönüşüme verilen cevap; genellikle büyük bir hayranlık ve bu hayranlığa eşlik eden korku ve uyum problemleri şeklinde olmuştur. İçinden geçilen dönemin mahiyetini kavrayabilmek ve derinlemesine analizlere girişebilmek kalabalıklar için zorlu bir görevdir. Öte yandan sanatçılar olayları geniş kitlelerden hatta kendileri dışındaki aydın kesimden daha farklı okuyabilmektedir. Bilişsel anlamda zamanda ileri doğru hareket edebilen ve anlık olarak yaşananların sonuçlarını kestirebilenler genellikle sanatçılar içinden çıkar. Marshall McLuhan'a göre sanatçılar dışındakiler topluma ve tarihe adeta dikiz aynasından bakmakta, olayları uzak bir geçmiş haline dönüştükten sonra analiz etmektedirler (McLuhan\&Fiore, 2001).

Batı'nın modernlik deneyimi söz konusu olduğunda da sanatçılar benzer bir rol oynamış görünmektedirler. Özellikle 19. yüzyılın ortalarından itibaren Avrupalı sanatçıların eserlerinde, Avrupa'nın yaşadığı deneyimle hesaplaşan, onu anlamlandırmaya çabalayan, 
bazen olumlayan, bazen yeren, modernite ile adeta bir ümit-korku ilişkisi geliştiren temalar ortaya çıkmaya başlamıştır. Bu temaların bir ucunda avangard harekette olduğu gibi modernite ile birlikte özerk bir alan haline gelen ve yaşam deneyiminden bütünüyle ayrışmış görünen sanata kurumsal olarak karşı çıkışa kadar uzanan örnekler, diğer ucunda ise modernlik tecrübesini adeta kutsayan ve onu bütün insanlığın ortak mirası/hedefi olarak gösterme çabasına girişen eserler vardır. Buna göre; modernizm söz konusu olduğunda bütün sanat yapıtlarının, eserlerin ve akımların ortak özelliğinin, bir övgü yahut yergi şartına bağlanmaksızın "modern durum" konulu konuşmalar şeklinde ortaya çıktığını söylemek yerinde olacaktır.

\section{Sanatın Otonomisi: Burjuva ve Modernist Zihin}

Modernizmi ortaya çıkaran zihin durumunun, düşüncenin aşkın olandan ayrılmasından sonra, estetik bakışın dünyaya ve burjuva toplumunun kendisine yönelmesi ile ilişkili olduğunu söyleyebiliriz. Bu anlamda ilk dikkate değer hamle Fransa'dan gelmiştir. Sanayileşmede, ezeli düşmanı olan İngiltere'nin gerisinde kalan Fransa, Charles Baudelaire'in nezdinde değiş̧en dünyanın tasvirini yapmaya girişmiş ve göründüğü kadarıyla bu konuda öncülüğü eline almıştır. Baudelaire, kalabalıkların yoğunlaşan kent ortamı içindeki yeni yaşam biçimini anlamlandırmaya ve endüstriyel teknolojinin toplum ve sanat üzerindeki etkilerine kayıt düşerek "kendi zamanını" açıklamaya çalışmıştır. Baudelaire'i dikkat çekici bir modernite soruşturmacısı haline getiren ve bu nedenle ilk modernistlerden biri olarak anılmasını sağlayan olguların başında pek çok sanatçının farkına vardığı halde görmezden gelmeyi yeğlediği temel meselelerle yüzleşme becerisi gelmektedir (Frascina\&Harrison, 1987). İngiltere sanayileşmeye uyum sağlarken, Fransa 19. yüzyıl ortalarında tarım toplumundan sanayi toplumuna geçişin henüz ilk aşamalarında yer almaktadır. Sanayi Devrimi'nin yarattığı kültürel değişimler öyle büyük ve kapsamlıdır ki pek çok sanatçı için bunları görmezden gelmek çok daha konforlu görünmektedir. Özellikle sanatın içeriği geleneksel mi çağdaş mı olmalı, yeni çağa uygun sanatsal teknikler nelerdir, türünden büyük sorular, sanatçıların zihnini fazlasıyla meşgul etmektedir. Bu sanatsal çıkmazı aşabilen ve "yeni içeriği", "yeni içeriği ifade etmenin yeni araçları" ile harmanlamayı başarabilenlerden biri Baudelaire olmuştur. Böylece hem çağdaşlarını hem arkasından gelen kuşakları etkilemiştir (Willette,2010).

Baudelaire'le aynı çağda yaşayan Gustave Fleubert benzer bir açılımı romanda, Edouard Manet ise resimde gerçekleştirmiştir (Reed, 2003). Modernist çatı altında ilk ortaya çıkan akım Realizm olmuş, insan yaşamına ve doğaya gerçekçi bakışla üretilen sanat eserleri ortaya çıkmıştır. Ancak bu bakış açısına tepkiler gecikmemiş, 1870'lerden itibaren Sembolizm adı altında realizme karşı çıkışlar baş göstermiştir. Yüzyılın sonlarına doğru 
modernizm çatısı altında hem realistler, natüralistler ve pozitivistler hem de sembolistler ve idealistler kendilerine yer bulabilmiş, bunlara sürrealistler, dadaistler, empresyonistler, kübistler ve diğer avangard cereyanlar eklenmiştir. Bu noktadan sonra modernist çerçevenin en büyük imtihanı, sanatın insan ve toplum yaşamından tamamen ayrışarak neredeyse otonom hale gelmesinin ve bunun yarattığı sarsıcı etkilerin sonuçlarıyla başa çıkmaya çalışmak olmuştur. Zira uç noktada avangardistlerin temsil ettiği akım, bir kurum olarak sanatın inkarına kadar işleri götürmüş, bu durum modernite projesinin derin bir başarısızlığı olarak algılanarak, postmodernizmin kullandığı argümanlardan birini oluşturmuştur.

Sanatın insan yaşamından ayrışarak otonom bir hale gelmesi esasen moderniteye içkin bir sorundur. Modernliğin başlangıcına dek sanat ya kutsal bir nesne yahut siyasal iktidarı yansıtan bir temsil objesi olarak konumlanmış ve insan yaşamının doğal akışının bir parçası olmuştur. Modernite ile birlikte sanatın geldiği nokta, önceki dönemden her anlamda farklı bir hal almıştır.

Peter Bürger, sanatın, moderniteye değin geçirdiği aşamaları üç tarihsel an olarak işaretlemektedir. Ona göre; başlangıçta "kutsal sanat" vardır. Orta Çağ'da Kilise'nin merkezinde yer aldığı sanat anlayışı, bu sanat anlayışına iyi bir örnektir. Bu aşamada sanat eseri, bir tapınma objesi olmak üzere üretilir ve sosyal bir kurum olarak "din" ile yakından ilişkilidir. Zanaatkarlar topluluğu tarafından kollektif olarak üretilir ve sanat eserlerinin tüketimi de yine kollektif olarak gerçekleşir. Sanatın bu ilk anından sonra ortaya çıkan ve onunla eşzamanlı olarak varlığını sürdüren "saray sanatı"dır. Bu türden sanatsal üretimin de kullanım alanı net bir biçimde çizilmiştir. Saray sanatı içinde, sanat eserinin temsili bir değeri vardır ve hükümdarın şanına yahut saray yaşamının görkemine hizmet eder. Saray sanatı da tıpkı kutsal sanatın, inanç yaşamının amaçlarına hizmet etmesi gibi saray yaşamının amaçlarına hizmet eder. Ancak "kutsal" bağlarından kurtulduğu için, kutsal sanata göre bir derece özgürleşmiş kabul edilebilir. Burada kutsal sanatla, saray sanatı arasındaki ayrımı oluşturan en önemli öğeler, üretim keyfiyeti ve tüketim performansının doğasında ortaya çıkar. Her iki sanatın tüketimi kollektif olarak gerçekleşiyor olsa da kutsal sanatın tüketim performansı da kutsaldır. ${ }^{5}$ Saray sanatı ise bireysel olarak üretilmekle beraber kollektif olarak tüketilir ancak tüketim performansının kutsal bir yönü yoktur. Sadece sosyal bir eylemdir. Sanatın son aşaması ise bugün de içinde bulunduğumuz aşama olan "burjuva sanatı"dır. Buna göre sanat; burjuvanın kendini anlamlandırma biçimlerinin tasviri olarak anlamlıdır. Burada artık

${ }^{5}$ Kutsal tüketim performansı olarak "ibadetten" söz edilmektedir. 
sanatın hayat pratiği içinde işlevsel bir yeri yoktur. Yaşam pratiğinin dışına uzanan bir alandan söz edilmektedir (Bürger, 1987).

Burjuva sanatı için anlamlı olan; insanı merkeze alan ve özellikle de burjuva yaşam biçimi ile ilgili olan görüngülerdir. Sanat, bu bakış açısından doğaya da Tanrı'nın yarattığı gizemli bir güzellik olarak değil, içinde insanın yaşadığı ve onun doğal çevresini oluşturan maddi bir yapı olarak bakar. Böylece sanat bir taraftan hem kutsal hem temsili bağlarından koparak özgürleşirken, diğer taraftan da giderek anlamını kendisinde bulan bir insan faaliyetine dönüşmüştür. Burjuvanın hakimiyeti ile imlenen bu çağda sanata, hayatın dışında suni yaşam alanlarının açılması, seçme işi ile ilgili profesyonellerin ortaya çıkması, dağıtımının yapılması ve bu dağıtımın ticari bir faaliyet olarak görülmesi, burjuva sanatının bu özelliği ile ilgilidir. Sanat özgürleşirken insan yaşamı içindeki ayrıcalıklı yeri de tartışmalı hale gelmiş gibidir ve bu yerin suni olarak yeniden üretilmesi gerekmiştir.

\section{“Modernite Projesi”nin Sonu mu?}

Böylece, insan yaşamından kopan ve giderek otonom bir karaktere bürünen sanat, "modernlik projesi"nin en büyük başarısızlıklarından biri olarak görülmüş, konu üzerinde uzun tartışmalar ve soruşturmalar yürütülmesine neden olmuştur. Bu durumu büyük bir hayal kırıklığı olarak gören Habermas, konuyu başlangıcından itibaren ele almıştır. Ona göre; kültürel modernlik dinde ve metafizikte ifadesini bulan objektif aklın üç ayrı alana ayrışması ile karakterize olmaktadır. Bunlar; bilim, ahlak ve sanattır. Bunların ayrışmasının nedeni 18. yüzyılda din ve metafiziğin yekpare dünya görüşlerinin yıkılmış olmasıdır. Eşzamanlı olarak da objektif bir bilim, evrensel bir ahlak ve yasa ve kendi iç mantıkları ile uyumlu bir sanat inşa etmeye çalışan Aydınlanma filozofları tarafından modernlik projesi formüle edilmiştir. Aydınlanma filozofları, modernlik projesi ile bu üç alanın bilişsel potansiyelini serbest bırakmayı ve ortaya çıkacak birikimi gündelik hayatın rasyonel organizasyonu için kullanmayı amaçlamışlardır. Ancak bu alanlar için talep edilen otonomi bir noktadan sonra problem çıkarmaya başlamış ve sanatın, kültürün ve hatta felsefenin inkarına kadar uzanmıştır (Foster, 1987).

Sanatın bu şekilde inkâr edilmesi ve kurumsal olarak saldırıya uğraması günümüzde etkilerini sürdürmeye devam etmekte ve sanat hakkında düşünenleri büyük çıkmazlarla karşı karşıya getirmektedir. Müzelerde tuval üzerinde yağlı boya tablolar veya mermer heykeller yerine tuğla yığınları ile karşılaşılması, gösterişli konser salonlarında icra edilen, geleneksel melodiler yerine, dinleyicilerden sahile kendi portatif radyolarını getirip istedikleri istasyondan seçtikleri müziği yüksek sesle yayınlamalarından oluşan 
"konserler"in icra edilmesi (Zolberg, 2015), boş bir çerçevenin yahut duvara koli bandı ile yapıştırılmış bir muzun sanat eseri olmak hüviyeti ile yüksek meblağlara alıcı bulması türünden garabetler yaşanmaktadır. Habermas, böylesine otonom ve varlığı kendinden menkul sanatın, bir tepki olarak dogmacılık ve ahlaki tutuculuğa yol verdiğini, modernlik projesine dönük karşı çıkışların başlıca nedeninin bu olduğunu savlamıştır. Habermas bir antimodernite hareketi olarak gördüğü postmodernizmin (Zolberg, 2015) ve modernlik öncesinin dokunuşu ile biçimlenen diğer antimodernlik hareketlerinin politik iklimde de karşılığının oluştuğunu endişe ile ifade etmektedir (Zolberg, 2015). Moderniteden ve modernlik projesinden ümit kesilmemesini, nihai anlamda moderniteyi inkara dönüşen abartılı (extravagand) programların hatalarından ders alınmasını istemektedir. (Zolberg, 2015)

"Modernite projesi" nin, en başta önermiş olduğu "araçsal us"un gelişmesine bağlı olarak, bilim, ahlak ve sanatın kendilerine özgü ussallıklarını arttırmaları, böylece kendi özel alanlarında ürettikleri bilginin gündelik hayata aktarılması yoluyla insanlığın özgürlüğe ve mutluluğa kavuşacağı inancı böylece yitime uğramıştır. İnsani sorunlar günümüzde hala çözümsüz kalmaya devam etmektedir. İnsanlık ne özgürlüğe ne de mutluluğa ulaşabilmiş, aksine modernite, Weber'in tespitiyle, insanlığı iki büyük problemle karşı karşıya bırakmıştır: Anlam kaybı ve özgürlük kaybı (Atiker, 1998). Bu sorunlar, Batı-dışı için üretilen kalkınma, gelişme, ilerleme söylemleri ve "modernleşme kuramı" gibi entelektüel paketlemeler ve "küreselleşme" gibi siyasal projeler eliyle tüm dünya sathına yayılmakta, hatırı sayılır bir teknik ilerleme ile seyreden modernlik projesi derinleştikçe, insanlığın yalnızlığı ve anlam kaybı da derinleşmektedir.

\section{Sonuç}

Modernite'yi 19. yüzyıldan sonraki tarihsel dilimde, Batı'nın kendi tecrübesinin toplamına verdiği ad olarak, "modernizm"i de bu tecrübeyi ortaya çıkaran zihin durumu ile ilişkili olarak okumak mümkündür. Batı tecrübesini anlaşılır hale getirme çabasıyla bizzat Batılı düşünce insanları tarafından ortaya konulan bu kavramlar, Batı bağlamında gerçekten anlamlı bir zemine oturmaktadırlar.

Türkçe'de modernite ve modernlik kelimeleri eş anlamlı sözcükler olarak birbirlerini ikame eden kavramlardır. Ancak modernizm farklı bir anlam alanına sahip olmasına rağmen sıklıkla moderniteyi anlatmak için de başvurulan bir kavram olarak karşımıza çıkmaktadır. Kavramları ve kuşattıkları anlam alanlarını yerli yerine oturtmak hem bu kavramlarla ifade edilmeye çalışılan toplumsal ve tarihsel olaylara ilişkin daha net bir görüntüye sahip olmak hem de bu kavramlarla ilişkili sonraki tartışmaların anlaşılması 
açısından önemlidir. Batı dışından bakanların da sıklıkla tükettiği ve yoğun bir biçimde tartışarak kendi bağlamlarına taşıdığı bu kavramlar Batı entelektüel ikliminin, Batı tarihsel ve toplumsal zeminini anlamak için ürettiği kavramlardır. Gerek moderniteye gerekse modernizme birer kavram olarak mahiyetini kazandıran en önemli özellik budur.

Modernite ve modernizm tartışması, Batı'nın. 19. yüzyılda tüm dünya sathında hakim bir siyasal ve ekonomik güç olarak ortaya çıkması sürecini konu alan Batı içi bir tartışmadır. Tarihsel olarak önce Avrupa kıtasının ardından da Amerika Birleşik Devletleri'nin büyük hegemon güçlere dönüşmeleri süreci, tüm dünya üzerinde etkilerini göstermeye başlamadan önce, ilk etkilerini Batı coğrafyasında göstermiştir. Büyük ekonomik ve siyasal değişimler, Batı'nın Orta Çağ'dan kalma yapısını neredeyse tamamen değiştirmiştir. Orta Çağ kurumları bütünüyle yıkılıp, yerlerini, yeni kurumlara bırakırken, toplumsal anlamda da büyük travmalar ortaya çıkmıştır. Batı, aynı anda hem siyasal ve ekonomik başarılarını yönetmek ve onların kalıcı hale gelmesi için çabalamak hem de ortaya çıkan toplumsal sorunları ele almak durumunda kalmıştır.

Batı'da kapitalizmin ortaya çıkması ile işaretlenen bu süreç, kapsamlı bir zihinsel dönüşümle kol kola yürümüştür. $O$ güne dek insan ve toplum yaşamını düzenlediği düşünülen vahiy kaynaklı evren ve toplum anlayışı tamamen terkedilmiş, yerini, akıl kaynaklı bir evren ve toplum anlayışına terk etmiştir. Bu tasavvur içinde insan kendisinin efendisidir ve doğa içinde nasıl yol alacağı hakkında söz sahibi olan da yine kendisidir. Akla dayanan ve insanı kendisinin efendisi olarak gören bu anlayış, Avrupa'nın o güne dek bilinen toplumsal yapısını da parçalamıştır. Ruhbanlar, soylular ve halktan oluşan üçlü yapı çözülmüş, soylular toplumdaki öncü rollerini burjuvalara devretmiştir. Ortaya çıkan yeni toplumsal formasyon yeni tür üretim ilişkilerinin önünü açmış, kapitalizm denen ve emperyalizmle kol kola tarih sahnesine çıkan yeni tür bir ekonomik anlayışı üretmiştir.

Kapitalizmle birlikte artık ekonomi hem siyasal meşruiyetin hem de toplumsal yaşamın temel kaynağı haline gelmiş ve üretim ilişkileri insan yaşamını belirleyen en temel parametre olarak ortaya çıkmıştır. Seri üretim olarak adlandırılan, makinelerin kullanıldığı, bölünmüş görevlerin bir bandın etrafında durmadan akmasından ve insanın da o bandın bir uzantısı olarak aynı mekanik hareketleri sürekli olarak tekrarlamasından oluşan üretim biçimi, mekanistik bir tasavvurun yerleşmesine zemin hazırlamış ve insan yaşamını makinelerin belirlemeye başladığı bir aşamaya geçilmiştir. Teknolojinin kullanımı arttıkça, insan yaşamı üzerindeki bu etki de giderek artarken, insan makine ilişkisinde, tarihte ilk defa, insanın değil makinenin süreçlerin başlatıcısı haline geldiği, 
makinenin hiyerarşik olarak insanın üzerinde yer almaya başladığı yeni bir dönem açılmıştır.

Makinelerin belirleyiciliğinde yürüyen mekanistik evren ve toplum anlayışı, ilk etkilerini insanın doğa ile olan ilişkisinde göstermiştir. İnsan için doğa fethedilmesi gereken bir entiteye dönüşürken, insanın doğayı zaptetmek üzere verdiği mücadele, onun doğayı istediği gibi sömürebilmesinin meşru nedeni olarak ortaya çıkmıştır. Doğayı "karşılıksız bir hediye" olarak gören insan, sosyal Darwinizmin etkisi ile başka insanları da zaptedebileceği ve sömürebileceği varlıklar olarak algılamaya başlamıştır. Kapitalizme ve onunla kol kola yürüyen emperyalizme enerjisini veren en önemli felsefi dönüşüm bu doğa ve insan anlayışı olmuştur. Dünyayı ve toplumu kendi aklı önderliğinde yeniden örgütleyen insan, serbest piyasanın ve tüketim toplumunun önünü açmış, değişen ilişkiler yeni bir yaşam biçimini ortaya çıkarmıştır. Batılı sosyologların, geriye dönük olarak modernite (modernlik) olarak adlandırdıkları yeni durum, başta kentlerde ortaya çıkan ve kent dokusu içinde şekillenen yeni bir yaşam biçimini ve bu yeni yaşam biçimine bağlı olarak yeni tür bir estetik duyuşu beraberinde getirmiştir. Batı'nın yeni şartlarına özgü bu estetik duyuş, dikkatini yeni dönemin hakim sınıfı olan burjuvaziye yöneltmiştir. Doğayı tanrının yarattığı ve insanın okuması gereken bir kitap olarak değil, tanrısal tarafı olmayan, insanın içinde yaşadığı doğal çevresi olarak algılayan bu anlayış insanı da tanrısal planın bir aracı olarak değil, kendi kaderinin hakimi olarak görmektedir. Bu tasavvurun sonucunda ortaya çıkan estetik duyuş, sanatın pek çok alanında verdiği eserlerle modernitenin kültürünü inşa etmiş ve karşımıza modernizm olgusunu çıkarmıştır.

Modernizmin, moderniteye inanan, onun insanlık tarihinde büyük bir kırılma olduğunu düşünen ve Batı'ya özgü bir başarı anı olarak tanımlayan pek çok düşünürü karşı karşıya getirdiği en büyük meydan okuma, onun, modernlik projesine dönük yıkıcı sanatsal üretimleri de içinde barındırıyor olmasıdır. Zira sanatı, ahlakı ve düşünceyi tanrısal bağlarından kopartan Aydınlanma projesinin bir devamı olarak modernlik projesi, kendi özerkliğini ilan eden sanatın ve hatta felsefenin sınırsız bir topoğrafyada ilerlerken kendisini inkar edecek bir noktaya gelebileceğini öngörmemişlerdir. Sanata ve felsefeye modernlik projesini topluma yayacak mekanik birer araç olarak bakan modernite savunucuları, özellikle sanatın kendini inkar eden ve Habermas'ın bakış açısı ile "antimodernite"ye yol veren uygulama biçimleri nedeniyle büyük bir şaşkınlığa düşmüş görünmektedir.

Böylesine karmaşık bir zeminde ortaya çıkan ve devinimlerini hala tamamlamamış söz konusu kavramların, özellikle Batı-dışında bir takım ideolojik yüklemelerle anlam 
kaymalarına uğratıldığı görülmektedir. Bu durum modernite-modernizm ekseninde Batı-dışı bağlamda yürüyen tartışmaların ve bunlara yaslanarak ortaya çıkan sonraki tartışmaların zeminlerini kayganlaştırmakta ve bu kavramlar etrafındaki sis bulutunu meydana getirmektedir. Böylece Batı-içi bağlam için nispeten açık olan bir tartışmanın, Batı-dışından olaylara bakanlar açısından son derece karmaşık bir hale geldiği görülmektedir. Bu kavramsal sis bulutunu ortadan kaldırmanın ilk adımı; modernitenin ve modernizmin, afaki bakıldığında son derece yekpare görünen yapılarına karşılık, Batı içinde derin kırılmalar ve hala devam eden sarsıcı tartışmalar eşliğinde ortaya çıktığını hatırda tutmak olacaktır.

\section{Kaynakça}

Altun, F. (2018). Türkiye'de Seküler ve Inanç Temelli Sivil Toplum Kuruluşlarının 'Toplumsal Fayda' Yaklaşımı: Çağdaş Yaşamı Destekleme Derneği ve Türkiye Gençlik ve Eğitime Hizmet Vakfı Örnekleri. (Yayımlanmamış Doktora Tezi).

Altun, F. (2020). "Hakikatten Öte Köy Var mı?", Kriter, 5 (46). https://kriterdergi.com/fatmanuraltun/hakikatten-ote-koy-var-mi, Erişim Tarihi: 21.02.2021.

Arnold, D. (2001). Coğrafi Keşifler Tarihi (1400-1600). (Çev. O. Bahadır). İstanbul: Yöneliş Yayınları.

Atiker, E. (1998). Modernizm ve Kitle Toplumu. Ankara: Vadi Yayınları.

Bellamy, E. (2020). Geriye Bakış, 2000'den 1887'ye. (Çev. F. Kâhya). İstanbul: Türkiye Iş̧ Bankası Kültür Yayınları.

Bottomore, T. B. (2000). Toplumbilim. (Çev. Ü. Oskay). İstanbul: Der Yayınları.

Bottomore T. B. (2015). Toplumbilim, Sorunlarına ve Yazınına Illişkin Bir Kılavuz. (Çev. Ü. Oskay). İstanbul: İnkılap Yayınları.

Bürger, P. (1987). Theory of the Avant-Garde, (Ingilizcesi M. Shaw). Minneapolis: University of Minnesota Press.

Capra, F. (1992). Batı Düşüncesinde Dönüm Noktası. (Çev. M. Armağan). İstanbul: İnsan Yayınları.

Çiğdem, A. (1 992). Akıl ve Toplumun Özgürleşimi, Jürgen Habermas Üzerine Bir Çalışma. (Çev. Y. Aktay). Ankara: Vadi Yayınları.

Çiğdem, A. (1997). Bir Imkân Olarak Modernite, Weber ve Habermas. İstanbul: Illetişim Yayınları.

Darwin, C. (1997). The Origin of Species. London: ElecBook Press.

Delanty, G. (2015). Bir Kavramın Anatomisi, Topluluk. (Çev. F. Bilge Atay). İstanbul: Everest Yayınları.

Everdell, W. R. (2007). Illk Modernler, Yirminci Yüzyıl Düşüncesinin Kökenlerine Illişkin Profiller. (Çev. H. Kocaoluk). İstanbul: Yapı Kredi Yayınları.

Frascina, F. ve Harrison, C. (1987). Modern Art and Modernism, A Critical Anthology. New York: Harper\& Row Publishers.

Freyer, H. (2012). Sosyoloji Kuramları Tarihi. (Çev. T. Çağatay). İstanbul: Doğu Batı Yayınları.

Habermas, J. (1983). "Modernity- An Incomplete Project", H. Foster (Ed.), The Anti-aesthetic içinde (ss. 3-15). Washington: Bay Press. 
Giddens, A. (1994). Modernliğin Sonuçları. (Çev. E. Kuşdil). İstanbul: Ayrıntı Yayınları.

Giddens, A. ve Sutton, P. (2018). Sosyolojide Temel Kavramlar. (Çev. A. Esgin). Ankara: Phoenix Yayınevi.

Henry, J. (2016). Bilimsel Düşüncenin Kısa Tarihi. (Çev. A. M. Şengel). İstanbul: Akılçelen Kitapları. Kahraman, H. B. (2000). Türk Şiiri, Modernizm, Şiir. İstanbul: Büke Yayınları.

Küçük, M. (2018). Modernite versus Postmodernite. Ankara: Say Yayınları.

Landes, D. S. (1995). Kapitalizmin Doğuşu. (Çev. S. E. Gündüz). İstanbul: İnsan Yayınları.

McLuhan, M. ve Fiore, Q. (2001). Medium is the Message. California: Gingko Press.

Nadel, G. H. ve Curtis, P. (1966). Imperialism and Colonialism. New York: The Macmillan Company.

Parsons, T., Shils, E., Naegele, K. D. ve Pitts, J. R. (1961). Theories of Society, Foundations of Modern Sociological Theory, Volume I. New York: The Frees Press of Glencoe Inc.

Patel, R. Ve Moore, J. W. (2019). Yedi Ucuz Şey Üzerinden Dünya Tarihi, Kapitalizm, Doğa ve Gezegenin Geleceği için Bir Rehber. (Çev. S. Gündüz). İstanbul: Kolektif Kitap.

Reed, A. (2003). Manet, Flaubert, and the Emergence of Modernism, Blurring Genre Boundaries. Cambridge: Cambridge University Press.

Ritzer, G. (1998). Toplumun McDonaldlaştırılması, Çağdaş Toplum Yaşamının Değişen Karakteri Üzerine Bir Inceleme. (Çev. Ş. Süer Kaya). İstanbul: Ayrıntı Yayınları.

See, H. (2001). Modern Kapitalizmin Doğuşu. İstanbul: Yöneliş Yayınları.

Stiglitz, J. E. (2014). Eşitsizliğin Bedeli, Bugünün Bölünmüş Toplumu Geleceğimizi Nasıl Tehlikeye Atıyor? (Çev. O. İşler). İstanbul: İletişim Yayınları.

Ünsaldı, L. ve Geçgin, E. (2019). Sosyoloji Tarihi, Dünyada ve Türkiye'de. Ankara: Heretik Yayınları.

Willette, J. (2010). Charles Baudelaire, Author Of Modernism. https://arthistoryunst uffed.com/baudelaire- modernism/Erişim Tarihi: 11.04.2021.

Winks, R. W. (1969). The Age of Imperialism. New Jersey: Prentice-Hall, Inc.

Zijderveld, A. C. (2007). Sahnelik Toplum, Sosyolojinin Yeniden Tanımlanması. (Çev. K. Canatan). İstanbul: Pınar Yayınları.

Zolberg, V. L. (2018). Bir Sanat Sosyolojisi Oluşturmak. (Çev. B. Okucu Özbay). İstanbul: Alfa Yayınları. 